\title{
COMBATTANTS AND ANTI- COMBATTANTS (COLLABOS): CONGOLESE TRANSNATIONAL POLITICS IN PRETORIA
}

\section{Saint José Inaka Department of Sociology \\ Human Economy Programme, University of Pretoria}

\section{Abstract}

This paper is concerned with the transnational political activities of Congolese nationals in Pretoria. The relationship between the migrants is marked by ethno-regional and political rivalry between two groups living in Pretoria, namely the 'combattants' and 'anti-combattants'. The paper argues that there is a dialectical interaction between Congolese transmigrant political activities, both in the Democratic Republic of Congo and in South Africa.

These transnational political activities have an impact on both the Congolese and the South African political scenes. Most importantly, the intra-Congolese rivalry is not only intermittent, but some of its dynamics are influenced by local politics back in the Democratic Republic of Congo. Following ethnographic research conducted among Congolese migrants between 2011 and 2013, this study revealed that grassroots political activists performed a key role in the Congolese transnational ethno-regional and political rivalry in Pretoria.

\section{Introduction}

This paper explores the escalation of Congolese ${ }^{1)}$ transnational political activities in Pretoria between the end of 2011 and the beginning of 2012. Ethnicity, regionalism, and political rivalries constituted major influences on these activities. Principally, these conflicts brought into opposition Congolese from the East, who are Swahili speakers and 
mostly pro-Kabila supporters, (pejoratively termed collabos), ${ }^{2)}$ and Congolese from the West, who generally speak Kikongo, Lingala and Tshiluba, also known as combattants, ${ }^{3)}$ and are generally in the antiKabila camp. Joseph Kabila, who became President of the Democratic Republic of Congo (DRC) in 2001, shortly after the assassination of his father and former president Laurent-Désiré Kabila, fought as part of the rebel forces that helped his father depose President Mobutu Sese Seko in 1997.

In view of the fact that the rivalry of these two opposing groups appears like a "dichotomy of interests between movement and countermovement" (Tilly 1993-1994), the main question this paper aims to explore is: how do Congolese transnational political activities influence the political scene in the DRC and in South Africa? Furthermore, to what extent do the political activities of both countries influence Congolese transnational political activities in Pretoria?

To answer these questions, this paper has five main parts. The first part succinctly attempts to identify gaps in the literature on transnational political studies and discusses the theoretical framework for the study. The second part provides a historical overview of Congolese political transnationalism in South Africa. The third part touches on the impact of the division between the combattants/anti-combattants in the DRC. The fourth part analyses the influence of South African politics on the political behaviour of the combattants/anti-combattants. The last part assesses the impact of the conflict between the combattants/anticombattants in South Africa.

\section{Theories on transnational politics}

Since transnationalism and conflict are central to this study, it is necessary to look at literature that informs debates about transnational politics and diasporic political conflicts. However, due to space constraints, this article cannot extensively explore these two large bodies of literature. Nevertheless, it is crucial to emphasise that the literature on transnational politics covers various phenomena, including transnational election campaigns and/or transnational voting (for example, Itzigsohn et al 1999; Østergaard-Nielsen 2003), contributions to peace building or democratisation (Lyons 2009); dual or multi citizenship issues (Swyngedouw and Swyngedouw 2009); and transnational advocacy networks (Shawki 2010) among others. 
However, many of these studies pay less attention to transnational politics based on ethno-regional and political conflicts among immigrants. Another particularly less studied feature is the fact that politicians from sending countries conduct election campaigns among their compatriots in the diaspora, who curiously do not have voting rights back home.

Considering the landscape of the Congolese East-West conflict in Pretoria, it is indeed relevant to scrutinise this issue from an ethnicity and regionalism perspective. Some authors suggest that "ethnicity is highly relevant to the study of immigration, as a source of boundarymaking" (Elias 1994; Tilly 2004 cited in Boccagni 2013: 58). Along this line, Boccagni (2013: 58) contends that looking at ethnicity informs the processes of distinction and boundary making even among immigrants from the same community.

Nevertheless, these authors' views on ethnicity seem rather thin on facts because they do not take into consideration many other factors influencing transnational political conflicts based on ethnicity and regionalism. Therefore, Basedau and Stroh (2012: 6-21) argue that ethnicity is just one among a number of factors that play a role in diasporic political conflicts. They consider that when compared with ethnicity, regionalism has a greater impact. This view is partly consonant with the combattants/anti-combattants rivalry as a result of which Congolese regionalism prevails upon ethnicity.

Theoretically, this paper draws on Bauböck's (2003) assumptions on transnational politics. It also uses Guarnizo, Portes and Haller's (2003) theories of the contexts of migration, and theory of social networks. Given the antagonistic essence of Congolese transnational politics in Pretoria, Tilly's (1993-1994) view on the conflicting claimmaking between movements and counter movements also explains the extraterritorial political struggle between combattants and anticombattants.

To this end, Bauböck (2003: 700) posits that immigrants' political transnationalism affects both the institutions of the country of origin and the receiving state. This article therefore argues that there are conflicting dialectical interactions between Congolese political activists in Pretoria, in both their receiving country, and their home country the DRC. Nevertheless, this political turmoil is neither static nor everlasting. Rather, this temporal dynamic is mostly influenced by the national political situation in the DRC. 
In their conceptualisation of transnational politics, Guarnizo, Portes and Haller (2003: 1215-1218) suggest that "potential determinants of immigrant transnationalism can be drawn from three different theoretical literatures', namely the classical theories of immigrant assimilation; the context of immigrants" incorporation into host societies theory; and the social networks theory.

Regarding the theory of immigrant assimilation, some scholars assert that "the longer immigrants live and are socialised into the ways of the host society, the greater the likelihood of their becoming thoroughly absorbed in it". These scholars argue that "to be naturalized as citizens of the receiving country seems like 'a natural barrier' to the continuation of political transnationalism" (Warner and Srole 1945; Gordon 1964; Alba 1985 cited in Guarnizo, Portes and Haller 2003: 1215-1216). However, the findings of some recent studies question these views.

In their research among Salvadorians, Colombians and Dominicans in the United States (US), Guarnizo, Portes, and Haller (2003: 1238) concluded that "length of residence in the United States does not reduce interest or involvement in home country politics, but actually increases it". Likewise, Landau (2009: 205) found that Congolese and other immigrants in Johannesburg remained loyal to their country of origin. Inaka and Trapido (2014: 168) also demonstrated that whether they were naturalised South Africans or not, Congolese kept close political connections with the DRC. In short, this theory of assimilation does not seem to explain the involvement of combattants/anticombattants in the Congolese transnational political activism in Pretoria.

Regarding the migration theory, Guarnizo, Portes and Haller (2003: 1217-1218) propose that immigrants' adaptation is affected by their contexts of exit and reception. This implies that the more the contexts of reception appear negative for immigrants, the more they take interest in the politics of their country of origin and vice versa. In essence, this theory suits this study, which suggests that because South Africa's stringent immigration rules do not facilitate immigrants' political incorporation, most Congolese maintain political bonds with their home country.

Regarding the social network theory, Guarnizo, Portes and Haller (2003) argue that transmigrant political actors' social networks determine their political activities. In their own words, they (Gaurnizo et al 2003: 1218) predict that, "regardless of the motivations individuals 
have for engaging in political transnationalism, the latter will be conditioned by the size and spatial scope of their networks". Thus, this theory gives us insight into how Congolese transmigrant political activists and their home-based politicians make use of various networks in their transnational political activities in Pretoria.

This paper looks at the context of rivalry involving two groups of international migrants from the same country. One group consists of combattants who oppose the Congolese regime and its supporters; while the other group, composed of anti-combattants (pejoratively termed collabos), opposes the hegemony of the combattants. It follows that their rivalry concurs with Charles Tilly's (1993-1994) notion of conflict between movement and counter-movement. This situation is the fruit of dichotomy of interests and claim-makings a-la Charles Tilly. Accordingly, Tilly's (1993-1994) approach provides an opportunity for a sound understanding of combattant/anti-combattant conflicts.

In terms of methodology, this paper is based on ethnographic research, using techniques such as observation and in-depth life history interviews among 46 Congolese, as well as a wider set of informal conversations with many Congolese during or after political events.

After having placed the study in its theoretical and methodological framework, we take a synoptic look at the background of the Congolese transnational politics in Pretoria.

\section{Synoptic view of Congolese transnational politics in South Africa}

We can roughly date the origins of Congolese transnational politics in South Africa to the 1990s; around the period of the end of apartheid. That period coincided with the arrival of the first wave of Congolese immigrants to South Africa. This wave included many of the 'barons' of Mobutu Sese Seko's regime who were relocating their families to Pretoria. At the same time, the Congolese middle class started arriving in Pretoria to look for better-paid jobs (see Bouillon 1998). According to some informants, many of these middle class Congolese exhibited strong antipathy towards Mobutu, the then military dictator and President of the DRC, and his close entourage who fled to Pretoria. However, they were sympathetic to the non-violent opposition of the Union pour la Démocratie et le Progrès Social (UDPS).

Within the same context, some middle class (especially Swahili 
speakers from the East) also clandestinely participated in the rebel insurgency that, with help from Rwanda and Uganda, ousted Mobutu's regime. Evidence of the South African connection to the concealed transnational political activities is that when Laurent-Désiré Kabila ousted Mobutu in 1997, he appointed several middle class Congolese living in South Africa (such as Bizima Kahara, Kantumba Mwanke, Kikaya Bin Karubi) to his government (see Omasombo 2009).

Moreover, following the collapse of Mobutu, certain of his former collaborators went into exile in South Africa. They also started clandestinely supporting political activities in South Africa, which were strongly oriented against Laurent-Désiré Kabila's regime. Many of these went into informal alliances with their former adversaries (such as members of the UDPS) or armed opponents of 'the Kabila dynasty' (like the Rwandan-backed rebel group the RCD-Goma ${ }^{4}$ ).

That said, it is important to point out that contemporary Congolese transnational political activism in Pretoria has undergone profound mutation. First, since 2006, when the DRC organised its first democratic elections, Congolese activism no longer remained underground. Second, the appearance of new leaders of Congolese transnational politics from the lower strata of the migrant community, namely the informal working class, is another striking change. This shift in the class make-up of political activism is also linked to a third notable change, namely the rising importance of violence and ideologies around ethnoregionalism and nationalism. In such a context, the use of the language of violence and their visible activism in the field have compelled some middle class and elite politicians of the Congolese opposition to collaborate with them.

It should be noted that these trends that occurred in Pretoria markedly coincided with events back in the DRC, where there was an intensification of ethno-regionalism and political animosity between Congolese from the West and the East due to electoral issues in 2006 and 2011. This animosity therefore transcended Congolese boundaries and reached the Congolese diaspora in Pretoria. For example, anticombattants and combattants violently clashed in Sunnyside in December 2011.

Some Congolese in Pretoria often see ethno-regionalism as an ancient and profound cultural divide. However, the split is rather recent, and in its present form dates to the end of the Mobutu regime. It is important to highlight here that the West/East split, which aggravates 
present divisions, is in political terms recent. During the 1990s, perhaps the most significant ethnic political rivalry was between the Bangala people, who were largely closer to Mobutu, and the Luba people of Kasai, who were largely anti-Mobutu. Today, these two groups are both classed as 'Westerners' and are perceived as allies. The Luba people are now seen as a bastion of opposition sentiment, even though at independence they were fiercely divided between the Lulua from Kasai Occidental and the Luba from Kasai Oriental (see Verhagaegen 1966). This division is now forgotten.

Following this brief synoptic view of the historical evolution of Congolese transnational activities and ethnic-political tensions in Pretoria, we will now analyse how the combattants/anti-combattants rivalry influences Congolese national politics.

\section{Influence of combattants/anti-combattants tensions on the DRC politics}

The combattants/anti-combattants political activism influences the Congolese political scene. Indeed, Congolese politicians whether in or out of power seek to exploit the political division between Congolese immigrants. Most of these politicians were involved in Congolese transnational activism during the elections of November 2011. Such interference reinforced or caused some ethno-regional conflict among the Congolese in Pretoria, and manifested itself in the form of conflict between combattants and anti-combattants. It is indeed worth describing these Congolese protagonists and exploring how Congolese politicians interfere in their transnational activism in the following lines.

\subsection{Combattants}

As mentioned before, combattants refer to people, mostly from the west of the $\mathrm{DRC}$, who are against the regime of Congolese President Joseph Kabila. The configuration of their movement appears like an ethno-regional coalition of Congolese immigrants, speaking Lingala, Tshiluba, and Kikongo, against their eastern compatriots mostly the Swahili speakers.

It is not clear which segment of the opposition in the DRC these combattants represent. Most of them often cite Honoré Ngbanda (former Mobutu's advisor in charge of security) or Etienne Tshisekedi, 
leader of the UDPS, as their heads. Nevertheless, it is not very clear if any of them has any direct control over the combattants' activities in Pretoria. It is interesting to note that these two were fierce political opponents in the 1990s. Moreover, they view other opposition leaders, not entirely without justification, as being on the payroll of Joseph Kabila and are often referred to as partis alimentaires. ${ }^{5)}$ Questioned on this issue, a well-known combattant described their movement as follows.

Our movement does not belong to a political party. It is a group of Congolese patriots wanting to liberate their country from the Rwandan's occupation and the dictatorship. [...] We do not have leaders. Our leader is any Congolese who is ready to die for our country. We are like deaths. The deaths do not have leaders. They are all equals. We are all leaders also. [...] Among us, there are people who are members of political parties. However, we do not speak in the mane of $\mathrm{X}, \mathrm{Y}, \mathrm{Z}$ party. We accept the collaboration of the nationalist parties. [...] But attention, we do not deal with 'partis alimentaires' pretending to be at the opposition. We powerfully combat them because they are just 'collabos'.

It seems that combattants are willing to collaborate or support any Congolese (whether a political leader or not) who shares a similar ideology and/or ambitions with them. Still, they do not identify themselves with any leader within or outside their organisation.

Regarding their claims, some justify their actions as combattants with reference to the constant need to remit back home. They see this as a direct consequence of the Kabila regime's pauperisation of the Congolese people, whose survival is ensured thanks to remittances from the hard-earned cash of Congolese immigrants and exiles in places such as Pretoria. That said, the main bone of contention of the combattants is what they perceive as the foreign occupation of their country, with accusations of occupation/usurpation and dictatorship also being directed at President Joseph Kabila, who, as explained earlier, is viewed as a Rwandan citizen. This implies that a form of 'wounded' nationalism is the main language of political contestation in Congolese politics. This Congolese wounded nationalism looks analogous to what Gurmu (2013) has found among Ethiopians. According to Gurmu (2013: 1), Ethiopians' wounded nationalism is due to their resentment of humiliating defeats caused by Eritreans' secession and invasion of the country by an ethnic army.

Interestingly, the combattants often demonstrate a high level of 
political awareness and take actions that include mass demonstrations/ large-scale protests, ethno-nationalist propaganda, and intimidation against their adversaries. As they have adopted the language of violence in their extra-territorial political struggle, some even resort to physical violence against what they term collabos.

Regarding political awareness, combattants conduct campaigns aimed at sensitising Congolese and the international community about cases of human rights violation, dictatorship, and public mismanagement occurring in the DRC. Another main aim of such campaigns is to draw the attention of other Congolese to join their cause.

Regarding demonstrations or large-scale protests and international publicity, the end of 2011 and the beginning of 2012 were marked by the rise of Congolese demonstrations in Pretoria. In fact, in October 2011, combattants started with the organisation of peaceful marches in front of the embassies of the United States (US) and the DRC denouncing the Congolese electoral process that they described as biased towards Kabila. Their anger against the regime took a deadly turn in December 2011 following the re-election of Kabila. On this occasion, they attacked the Congolese Embassy in Pretoria and a Congolese diplomat was killed in the process.

The rift among Congolese in Pretoria goes beyond political alignment. The rivalry also takes on an ethno-regional dimension. For example, combattants disparage other Congolese from the East (the Baswahili). For them, it is abnormal for a real Congolese (a patriot) to support an 'oppressor' like Kabila. Thus, they consider all Kabila's supporters (mostly from the East) as Rwandans.

In the course of this research, it emerged that some informants from the West perceive Baswahili support for Kabila as misplaced, particularly because the latter appears to be unable to protect them against armed groups. A combattant was very explicit in this respect.

In all these troubles happening in the East, when we say what we should do, we must react, all and all. You will see there are people from the East who say: 'Kabila is our child; Kabila is Raiis'). In everything we speak, we do not see the East-West; we first see Congo. I believe that our brothers from the East sometimes refuse to understand. They believe that he (Kabila) is their child. It seems that Kabila is at first manhandling them, not us in Kinshasa.

As regards intimidation and or the threat of physical violence, com- 
battants have also severely restricted the activities of Congolese musicians living in the DRC from performing in Pretoria. They accuse these musicians of singing the praises of Kabila. The same treatment was also meted to some Congolese pastors (suspected of supporting Kabila). It is even worse for Congolese pro-Kabila politicians on whom they threaten to inflict the punishment of mutakalisation ${ }^{7)}$. This practice, which consists of the mediatisation of shaming rituals, looks more violent and humiliating than the American 'perp walk ${ }^{\text {(8) }}$ does (see Boudana 2014).

\subsection{Anti-combattants}

As combattants use various clichés against some Swahili speakers, the latter resent all of these derogatory terms. They find it extremely insulting and ethno-phobic that combattants treat them as Rwandans because in the current Congolese rhetoric, being a Rwandan means being an enemy of the DRC.

In resistance against combattants' hegemony, Swahili speakers identify themselves as anti-combattants. Actually, they are two kinds of 'anti-combattants', namely the Allemands, ${ }^{9)}$ (who are mostly pro-Kabila supporters from Katanga like Kabila himself) and other Swahili speakers. In terms of claim-makings, Allemands doggedly assert that Kabila is a pure Congolese and their hero. For them, Kabila restored peace, order, and democracy in the DRC after a long period of chaos. They also insist that Kabila is working hard for the progress of the DRC. For example, in the words of an Allemand:

Since 1996 until 2002, we underwent wars, many crises until Joseph Kabila reinforced peace and democracy [...] He organised the first democratic elections in the DRC. We voted for him. [...] Now, he is rebuilding our country and organising everything, we must give him more time.

Unlike the Allemands, the study noticed that many other anticombattants did not necessarily support Kabila during the election campaigns of 2011. They complained that Kabila was unable to bring about peace and develop their provinces. However, what led them to fight against combattants was the extreme rhetoric and violence towards all Swahili speakers in Pretoria.

As combattants physically attacked them and looted a shop of a 
Swahili speaking businessman, anti-combattants from other Congolese provinces joined Allemands to take revenge. Then, on 11 December 2011, their reaction was not only violent but also unexpected because of the view that combattants have Pretoria under their control. On that occasion, anti-combattants launched a surprise attack against combattants, while the latter were in a meeting at Jubilee Park in Sunnyside. It was the first time combattants were seen cowardly retreating from their favourite terrain. At the same time, some anti-combattants plundered the shop of a figurehead of combattants, a street vendor in Sunnyside.

Similarly, combattants/anti-combattants also made use of ethnoregional propaganda against Congolese from the west of the DRC. For example, they often stereotypically describe Congolese from the west of the country as louts, crooks, and braggarts.

In summary, all these ethno-regional and political animosities paved the way for politicians to conduct an election campaign among Congolese from the bottom. In this context of latent tension, Congolese politicians' electoral rhetoric further inflamed combattants/anti-combattants animosities.

\subsection{Interference of politicians on combattants/anti- combattants tensions}

Although Congolese living in South Africa could not legally vote in Congolese elections, the Congolese community in Pretoria was the target of some home-based politicians during the November 2011 election campaigns. In that period, delegations representing main segments of the Congolese ruling party and opposition vigorously campaigned among Congolese in Pretoria.

For opponents, the Congolese diaspora had the power to convince their relatives and others left in the DRC to vote for them. In their view, the fact that Congolese immigrants send remittances back home gives them the leverage to influence their families in the DRC.

In fact, pressure from home about remittance and employment problems are among the issues that Congolese immigrants and exiles encounter in Pretoria and throughout South Africa, as well as other places around the world. Aware of these problems, opposition politicians used appropriate language to woo their supporters in Pretoria. With their opportunistic discourses, they could harangue and galvanise Congolese to support them. Because of this political acumen, opposition 
leaders, above all allies of Etienne Tshisekedi, were cherished in Pretoria. To some extent, one can argue that they attained their objectives considering that combattants did indeed use multimedia to motivate Congolese back home to vote for Tshisedeki and his allies.

Kabila's opponents also argued that, immigrants' greater access to media, such as the internet, and their better understanding of Congolese political issues allowed them to influence their relatives back home. The perceived imperative to attract support among the diaspora is illustrated by the frequent claims by opposition that if they win power, they will recruit more workers among those who supported them within the diaspora. This point is illustrated by the following attempt by a combattant to convince me to join them:

My friend it is time to participate in the combat. Do not wait until it will be too late. Our leaders know us. [...] They cannot rely on unfamiliar persons. For an intelligent guy like you, this is the right time.

Overall, in terms of such popular mobilisation, President Kabila's camp was in an unfavourable position in Pretoria. The combattants created fear among them thereby depriving them of any platform to freely express their support to the incumbent.

Not cowed by intimidation, some pro-Kabila supporters went ahead and held meetings in secret locations in Pretoria. They also used tactics similar to those of their rivals. They indeed resorted to using mass media to broadcast pro-Kabila campaign messages in the DRC. Such broadcasts were aimed at portraying President Kabila as very popular among the 'high quality of Congolese people' living in Pretoria.

Their campaign was not limited to Congolese engaged in trade and other professions; in fact they also targeted students. For example, by October 2011, Congolese students at the University of Pretoria received a pro-Kabila delegation, supposedly sent by his wife Olive Lembe Kabila. This delegation promised to offer money and jobs, among other things to Congolese students in Pretoria. The delegation also handed an amount of R200 to each student, which some viewed as bribes. The delegation was furthermore accompanied by a crew of pressmen who could be seen filming the event, and these images were used in support of Kabila's electoral campaign.

In a bid to maintain loyalty among its supporters, I was reliably informed by some pro-Kabila supporters that they sometimes had opportunities to meet senior Congolese authorities who sneaked into South 
Africa without the knowledge of the combattants. They have also created an informal organisation of Kabila supporters apparently with the sole aim of making money. They demonstrate allegiance to the authorities, in exchange for money, which can be interpreted as a symbol of gratitude for their apparent political loyalty.

In fact, the involvement of Congolese politicians in the anticombattants' political activities in Pretoria demonstrates how "governments from the sending countries seldom initiate grassroots transnationalism, but the governments enter into the picture, as the importance of the phenomenon becomes evident" (Portes 1999: 466-467 cited by Bauböck, 2003 :8).

Generally, the findings related to this section confirm Itzigsohn and his collaborators' (1999: 324) theory on political transnationality. According to this theory, narrow political transnationality is based on a high level of institutionalisation and constant personal involvement. On the other hand, broad political transnationality is less institutionalised (informal) and sporadic because of the occasional personal involvement.

Broadly speaking, our empirical findings tend to concur with the above theory on a number of aspects, including; first, the study found that, despite their low degree of institutionalisation, the political activities of the combattants/anti-combattants in Pretoria influence policy-making back home. Second, their political activism is by and large circumstantial, and is motivated principally by national events such as the elections of November 2011.

On the other hand, the theory does not inform us about the extraterritorial ethno-regional and political conflicts among immigrants and the fact that politicians use these conflicts to their own advantage. Moreover, the fact that politicians from a sending country would invest so much effort in election campaigns targeted at migrants without voting rights has so far not been discussed in previous studies. Instead, studies have shown that politicians in sending countries carry out election campaigns targeted at migrant compatriots who can only vote for them through proxy, that is, through absentee ballots as absentee voters (Bauböck 2003; Itzigsohn et al 1999; Portes et al 1999; Guarnizo et al 1999). 


\section{Influence of South African politics on Congolese transnational politics}

The findings of the research unearthed three key facts. The first concerns how South African politics shape Congolese activists' political opinions and attitudes. The second explains the awakening of political consciousness among them, arising from their exposure to South African politics. The third is a Congolese perception of South Africa, especially its capital Pretoria, as an arena of political freedom and/or struggle.

South African politics influence Congolese political opinions and attitudes in three ways. First, the first-hand experience of South African politics strengthened animosity among combattants towards Congolese politicians working with Kabila. Second, such experiences also drove some former pro-Kabila supporters to change their opinions entirely about Congolese politicians. Third, some combattants, even anti-combattants, wish to export the South African democratic practices to the DRC.

Regarding the rise of the animosity toward Congolese political leaders, many combattants declared that their experience of living in a more democratic and well-managed country like South Africa, had increased their rancour towards what they see as corrupt and inept Congolese politicians. Critique of the current regime is expressed in terms of an absence of patriotism by the current leadership.

However, some pro-Kabila supporters said that the familiarity with South African politics pushed them to lose sympathy for Congolese authorities whom they used to support. As an example, a trader from Katanga (Kabila's province) explains how South African politics changed his political orientation.

Considering all that I observe here: how institutions are strong that help the population to be very well managed, who can rationally continue to support Kabila? In the past, I made mistakes. That was because of our (common) origins.

Regarding the desire to export South African democracy to the DRC, some combattants said they wanted to export the South African political system to the DRC to get rid of Congolese politicians and institutions. A combattant explicated as follows: 
It is not a shame to admit that South African leaders work for their people. [...] Thus, we must do the same in our country. We must imitate them; bring their political expertise at home. The revolution is necessary.

On the other hand, some anti-combattants want Kabila's regime to continue running the DRC, but to follow the example of South Africa. For example, one of them said:

The problem is that the President has several role models who he follows at the same time - Chinese, Indian, Eduardo Dos Santos, Mugabe, Zuma, Kagame, who muddle him. If I could talk to him, I would have told him to copy at least the 50 per cent of the South African politics [smile].

It is quite clear that the views of both combattants and anti-combattants about the Congolese leadership are quite similar. Irrespective of their political orientation, they all desire certain changes in the way their country is governed. However, they greatly differ about the ways in which to bring about change. Whereas the combattants advocate for revolution of the political system, the anti-combattants prefer reforms that do not alter political actors.

Interestingly, they have developed their opposing views partly because of their exposure to the South African democratic experience. This has enabled them to desire the South African political model to be replicated in the DRC. This echoes with Bauböck (2003: 707), who argued that, "the shared experience of democratic incorporation into the receiving state may feedback into transnational activities that aim at the democratising regional politics at home".

Regarding political awareness, and irrespective of their ethnoregional and political belongings, a majority of informants said that exposure to South African politics had greatly boosted their political consciousness. Accordingly, they argued that they now closely pay attention to Congolese politics. A number of them admitted to participating in Congolese transnational political activities in Pretoria. The following extract speaks volumes.

....in Congo, I did not really care about politics. [...] But here, [...], I started getting interested in politics. If I would have to take weapons in order to liberate my country [...], I will take them.

In addition, Pretoria appears to some combattants as the space of polit- 
ical freedom. However, anti-combattants do not have the same level of political freedoms within the Congolese community in Pretoria. Actually, the combattants seem to have more opportunities for lobbying, conducting campaigns, and canvassing support from civil society organisations. Anti-combattants, on the other hand, are somewhat deprived of an open political platform by combattants. The argument being that, they have the means and opportunities to support their leaders in the DRC, while combattants do not. Interestingly, the opposite phenomenon occurs in Pretoria.

Pretoria indeed appears to combattants as a suitable place to take revenge on their political adversaries. The latter have intimidated the pro-Kabila factions to the point where their actions can be compared to that of the fascist movements in Europe prior to the Second World War (see also Tilly 1993-1994: 2). To paraphrase Tocqueville (1990), the freedom, which Pretoria offers to Congolese, allows the combattants to exercise their tyranny over their adversaries.

\section{Influence of Congolese transnational politics in South Africa}

The array of Congolese transnational political activities in Pretoria exerts an influence on South African politics. The South African government's reaction to Congolese transnational politics is mainly based on two fears. The first is weariness of the consequences of the importation of Congolese national tensions into South Africa. The second is that President Zuma's entourage is less than happy at the prospects of losing personal economic interests in the DRC if they do not protect Kabila against his political opponents in South Africa.

Regarding the fears of importing ethno-regional and political conflicts in South Africa, since January 2012 local authorities have strongly reacted against Congolese political activism in Pretoria. Following several clashes that occurred in December 2011 between anticombattants against combattants, Pretoria's police feared escalating violence. In a bid to avoid further escalation, they detained some figureheads of the Congolese protagonist. Moreover, at the end of December 2011, the police obliged some well-known Congolese community leaders to meet together and find solutions to the challenge experienced by their community in Pretoria. 
The police's strategy was to create a forum for Congolese to identify the root cause of the conflict and to mitigate tension. If this had failed, Pretoria could have been the scene of unprecedented ethnic conflicts among Congolese immigrants. The South African Police's initiative of instituting a dialogue between different Congolese factions in Pretoria may be viewed as a laudable initiative aimed at seeking a politico-sociological solution to intra-Congolese conflict and also demonstrates how Congolese transnational political activities have an impact on the authorities in Pretoria.

Regarding the issue of protection of interests in the DRC by South African politicians, the Congolese opposition in general and the combattants in particular accuse the entourage of President Jacob Zuma of supporting the Kabila dictatorship because of their selfish business interests in the DRC. For them, the arrests and deportation from South Africa of some combattants is a clear indication of President Zuma's bias towards Kabila's regime, and it is generally perceived to be in exchange for concessions to exploit Congolese natural resources, particularly oil on Lake Albert (where Zuma's nephew Khulubuse has been a major beneficiary). However, Kabila's faction rejoices over the latter's apparent diplomatic skills that prevail on the South African authorities to clamp down on the combattants.

Indeed, January 2012 witnessed a massive crackdown by the South African police on the activities of some Congolese in Sunnyside. Similar operations took place in Yeoville in Johannesburg, with more than 150 Congolese detained in these two largely Congolese neighbourhoods of Gauteng province. Such operations led some informants to conclude that President Zuma and his entourage are supporting the regime of Kabila in exchange for private economic interests in the DRC.

The timeline of these events started on 6 December 2011, when combattants simultaneously protested against President Zuma in three South Africans cities, namely Pretoria, Johannesburg and Cape Town. On 5 December 2011, what ignited the fire was President Zuma's statement on the outcome of the Congolese elections. Although international observers of the Congolese elections, notably the European Union Commission and the Jimmy Carter Centre, sharply criticised the elections and deplored the lack of credibility and transparency, President Zuma was the first head of state to congratulate the Congolese for having organised "successful elections" (Peuchot 2011; see also The Presidency 5 December 2011). 
In reaction to this, the combattants took to the streets of Pretoria, Johannesburg, and Cape Town protesting against President Zuma. They carried posters saying that President Zuma should stay out of Congolese affairs (Radio Netherlands Worldwide 2011). They also accused President Zuma of supporting Kabila because he has financial interests in the DRC (Smillie and Serrao 2011).

In Johannesburg, as they attempted to march on the African National Congress (ANC) headquarters (Luthuli House), police fired rubber bullets at them (Mukhutu and Dlamini 2011). Some Congolese protestors stripped naked and shouted insults about Zuma, and some members of the ANC came out of their building and started fighting with them.

In Cape Town, combattants went to the building housing the office of the Premier of Cape Town, Helen Zille, where they sang and praised her for her anti-Zuma stance. As an influential politician, Zille made a speech saying she was wearing black clothes to show her sympathy with Congolese who left their country because of the lack of democracy and accountability (see Boloali 2011). In Pretoria, the police rapidly foiled plans to march on the Union Buildings, in the wake of protesters attacking the Congolese embassy.

In view of these facts, the police arrested a number of Congolese following clashes between expatriate supporters of President Joseph Kabila and that of opposition leader Etienne Tshisekedi (SAPA 6 December 2011). Some of those arrested were expelled from South Africa to Lubumbashi. There were also subsequent expulsions between January and April 2012, with over 81 people being expelled to Lubumbashi where they were imprisoned without legal proceedings (Dianzenza 2012).

In reaction, the Congolese opposition and some Congolese nongovernmental organisations (NGOs) accused Jacob Zuma's regime of expelling combattants because of their protests against rigged elections in the DRC. They argued that because the expelled combattants were sent to Lubumbashi (a Kabila stronghold), this clearly demonstrated Zuma's bias towards Kabila (Dianzenza 2012).

Meanwhile, the pro-Kabila faction went into propaganda overdrive and wrote articles praising the DRC and South African governments for their excellent collaboration aimed at punishing combattants. Jean-Luc Mushi-Mpaku (2012), for example, wrote an article in which he states that Kabila had persuaded the Zuma administration to silence 
combattants.

In view of these events, it can be concluded that President Kabila's government did influence the South African authorities' decision to arrest and expel combattants. This is seen in the views of both the anti- and pro-Kabila media in the DRC, who arrived at the same conclusion that Kabila had persuaded the South African authorities to act against his opponents based in South Africa.

Despite the lack of proof about the content of agreements between Zuma and Kabila about the arrests and expulsion of combattants, I could not find any evidence to attest the opinion of the combattants who argue that Zuma's support for Kabila is in exchange for economic interests in the DRC. Nevertheless, there is abundant literature that demonstrates the existence of strong individual business ties between Kabila's entourage and the Zuma clan, which does seem to raise questions. For example, the Congolese government has allocated important oil concessions in Lake Albert (considered as the most important oil find in Africa over 20 years) to companies (Caprikat and Foxwhelp) owned by the nephew of President Zuma, Khulubuse Zuma and his personal lawyer, Mark Hulley (see Brummer and Sole 2010; ICG 2012; Boisselet 2013).

This therefore feeds into allegations that the Zuma regime had perhaps reacted against combattants in order to protect its business in the DRC. Such assumptions are also based on the testimonies of two Congolese who were among the 81 deported to Lubumbashi. They informed me that in April 2012 when they arrived at the airport in Lubumbashi, they were issued death threats by soldiers, police, and agents of the Congolese secret service. Some of the threats were as follows:

Why did you choose South Africa for your so-called combat? Do you know how many trucks full of high-grade ore leave everyday Katanga to South Africa? Were you sure that South African authorities would lose all things they have in the DRC?

The above excerpt lends some credence to the assumption that Jacob Zuma's entourage had reacted strongly against combattants in order to protect their business interests in the DRC. This South African power elite's protectionist inclination toward the Congolese regime under Kabila supports Bauböck (2003), who points out that migrant transnationalism affects both the institutions of the country of origin and of the receiving. However, results do not sustain Bauböck's (2003: 708) 
hypothesis that "city administrations in the receiving state may become engaged in political campaigns against authoritarian regimes from where their immigrant communities originate". In the case of Congolese immigrants in Pretoria, there is no evidence attesting that Zuma's administration helps them in their extraterritorial struggle against the existing tyranny in their country.

\section{Conclusion}

This article shows that the Congolese transnational political situation in Pretoria is linked to issues of ethnicity and regionalism, which are sometimes causes of violence among Congolese in Pretoria. The historical view of the transnational political activities clearly indicates that the Congolese extra-territorial, ethno-regional and political tensions in Pretoria are dynamic and at the same time temporal processes, but not static in their historical essences.

In this regard, the paper also documents various changes of transnational political issues and actors. In line with this, it has shown that the emergence of the Congolese grassroots transnational political activism, led by those at the bottom, called combattants (known for their tendency to violence) and their adversaries, anti-combattants, is a remarkable change in the Congolese transnational politics in Pretoria. In brief, since the late 2000s, these activities have no longer been monopolised by the middle classes and elites as they had been before.

The article furthermore shows that Congolese transnational politics in Pretoria are also totally intertwined with the Congolese national political situation. The current Congolese East-West tension in Pretoria is related to a similar ongoing conflict in the DRC. Nevertheless, the Congolese transnational politics is an integral part of such conflicts and has an influence on the Congolese national political scene.

This paper proves that the Congolese immigrants' exposure to South African politics has an impact on their attitudes and opinions towards their own country. It also awakens their political consciousness and makes them consider Pretoria as a hospitable place for their extraterritorial political and ethno-regional struggles.

In this context, Congolese politicians look for support from Congolese transnational activists in Pretoria, especially during electoral campaigns. This involvement of politicians from a sending country during electoral campaigns targeted at people without voting rights, is some- 
thing that requires further investigation. This is also true for the implications on political actors (of the receiving country), in immigrants' transnational political activities in their sending country.

In addition, the meddling of the South African leadership in Congolese political affairs needs in-depth studies. Such a study if undertaken may shed more light on the veracity of transmigrants' perceptions of South Africa as a role model of democracy in the Southern African region.

\section{Endnotes}

1. All references to Congo or the Congolese in this essay refer to the inhabitants of the Democratic Republic of the Congo (DRC).

2. Collabos is the short form of the French word collaborateur which means collaborator. French were pejoratively using it against some of their leaders who collaborated with German invaders during World War II. It fits into a Congolese narrative about their country's occupation by outsiders and the citizens who accept to be led by foreign politicians. An important part of this narrative is the belief, widely held among the Congolese that Joseph Kabila is not the biological offspring of Laurent-Désiré Kabila, but the son of a Rwandan Tutsi (see Trapido, 2011).

3. In the present Congolese political popular jargon, a 'combattant' means someone who combats Kabila's regime.

4. RCD-Goma: Rassemblement Congolais pour la Démocratie means The Rally for Congolese Democracy.

5. Literally, partis alimentaires means 'food political party'. Actually, this word from the Congolese political jargon - means a political party that lacks base or seat, but plays a clandestine role of sustaining another well-established political party. Most of these political parties are reputed to be looking for financial support and employment from real political parties.

6. Raïs means president or king in Swahili and Arabic. Congolese use it as a friendly nickname for Joseph Kabila.

7. Mutakalisation is a slang Lingala word from the word Mutakala (means nudity). This means to beat up someone, then to undress her or him and finally to take his or her pictures (being unclothed) in order to publish them on media.

8. Perp walk or 'perpetrator walk' is a shaming ritual that consists, for the police, of marching a suspect in cuffs from the police station to the courthouse, before photo-reporters and cameramen, who are invited to take, and publicise, images of what then becomes an event.

9. Some Congolese from Katanga who, for complex historical reasons, see 
themselves as rivals of the Luba people of Kasai, often consider themselves Juifs: Jewish. Therefore, these people from Katanga have taken to identifying themselves as Allemands (Germans), that is, arch rivals of Juifs.

\section{Bibliography}

Basedau, M and A Stroh (2012), "How ethnic are African parties really? Evidence from four Francophone countries", International Political Science Review, Vol 33, No 1, pp 5-24.

Bauböck, R (2003), "Toward a Political Theory of Migrant Transnationalism", International Migration Review, Vol 37, No 3, pp 700-723.

Boccagni, P (2013), "'I'm not like all these Ecuadorians'. Promises and dilemmas of immigrants' selective ethnicity appropriation", Social Identities: Journal for the Study of Race, Nation and Culture, Vol 20, No 1, December, pp 57-73.

Boisselet, P (2013), Les Précieux Allié Sud-Africain de Kinshasa, 1 September. (Available: at http://www.jeuneafrique.com/Article/JA2746p028.xml0, last accessed 5 September 2013.)

Boloali, Z (2011), Colère des Congolais de Cape Town sur la Tricherie, 21 December. (Available at: http://www.youtube.com/watch?v=cxSwzXdqD14, last accessed 9 January 2012.)

Boudana, S (2014), "Shaming rituals in the age of global media: How DSK's perp walk generated estrangement", European Journal of Communication, Vol 29, No 1, January, pp 50-67.

Bouillon, A (1998), "New" African Immigration to South Africa, Cape Town : CASAS.

Brummer, S and S Sole (2010), Zuma Inc's DRC oil coup. (Available at: http:// mg.co.za/article/2010-07-30-zuma-incs-drfc-oil-and-the-tokyo-fator last accessed 30 July 2013.)

Dianzenza, L (2012), "Des Congolais expulsés d'Afrique du Sud détenus à la Prison de Kasapa", Les dépêche de Brazaville, No 1498, 24 May, p 6.

Guarnizo, L E, Portes, A and W Haller (2003), "Assimilation and transnationalism: Determinants of Transnational Politcal Action among contemporary Migrants", American Joiurnal of Sociology, Vol 108, No 6, pp 1211-1248.

Guarnizo, LE, Sanchez, A I and E M Roach (1999), "Mistrust, fragmented solidarity, and transnational migration: Colombians in New York City and Los Angelos", Ethnic and Racial Studies, Vol 22, No 2, pp 376-396.

Gurmu, L A (2013). Ethiopia: The Wounded Ethiopian Nationalism and Its Insecurity Dilemma. (Available at: http://www.gulelepost.com/2013/07/18/the-woundedethiopian-nationalism-and-messay-kebedes-recent-article/?, last accessed 10 August 2014.)

ICG (International Crisis Group) (2012), Black Gold in the Congo: Threat to stability or development opportunity? Africa Report No188, July. 
Inaka, S J and J Trapido (2015), "Congo-Gauteng: Congolese Migration to South Africa", in Hart, K and J Sharp (eds), Poeple, Money and Power in the Economic Crisis: Perspectives from the Global South. Oxford and New York: Berghahn Books

Itzigsohn, J, Cabral, C, Medina, E H and O Vazquez (1999), "Mapping Dominican Transnationalism: Narrow and Broad Transnational Practices", Ethnic and Racial Studies, Vol 22, No 3, pp 316-339.

Landau, LB (2009), "Living Within and Beyond Johannesburg: Exclusion, Religion, and Emerging Forms of Being", African Studies, Vol 68, No 2, August, pp 197 -214 .

Omasombo, J (ed) (2009), Biographies des Acteurs de la Troisième République. Tervuren: Royal Museum for Central Africa.

Østergaard-Nielsen, E (2003), "The Politics of Migrants' Transnational Political Practicces. Transnational Migration: International Perspectives", International Migration Review, Vol 37, No 3, pp 760-786.

Peuchot, E (2011), Mail Guardian. Africa's Best Read, 14 December. (Available at: www.mg.co.za/article/2011-12-14eu-discounts-chaotic-drc-election-results, last accessed 6 August 2013.)

Portes, A, Guarnizo, L and P Landolt (1999), "The Study of Transnaitonalism: Pitfalls and promise of an Engagement resaerch Field", Ethinic and Racial Studies, Vol 22, No 2, pp 217-237.

Radio Netherlands Wolrdwide (2011), DR Congo Protesters Clash with South Africa Police, 6 December. (Available at: www.rnw.nl/africa/bulletin/DRCongo-fears-results-volcano last accessed 5 August 2013.)

SAPA (2011), News24. Breaking News, 6 December. (Available at: www.news24.com/southafrica/news/DRC-protesters-angry-with-zuma20111205, last accessed 5 August 2013.)

Shawki, N (2010), "Transnational Advocacy network", Peace and Change, Vol 35, No 3, pp 381-411.

Smillie, S and A Serrao (2011), The Star, 06 January (Available at: www.iol.co.za/ the-star/congolese-protest-over-rigged-election, last accessed 5 August 2013.)

Swyngedouw, E and E Swyngedouw (2009), "The Congolese Diaspora in Brussels and Hybrid Identity formation: Multiscalarity and Diasporic Citizenship", Urban Research and Practices, Vol 2, No 1, pp 68-90.

The Presidency (2011), Statement on the Democratic Republic of Congo (DRC) Presidential and Parliamentary elections, 5 December. (Available at: www.info.gov.za/speech/DynamicAction, last accessed 6 August 2013.)

Tilly, C (1993-1994), "Social Movements as Historically Specific Clusters of Political Performances", Berkeley Journal of Sociology, Vol 38, pp 1-30.

Tocqueville, A D (1990), Democracy in America. Vol I and II. New York: Vintage. 
Trapido, J (2011), "The political economy of migration and reputation in Kinshasa", Africa, Vol 81, No 2, pp 204-205.

Verhagaen, B (1966) Rébellions au Congo, $1^{\text {st }}$ edition, Léopoldville-Bruxelles: Les Etudes du C.R.I.S.P. 